Provided for non-commercial research and education use. Not for reproduction, distribution or commercial use.

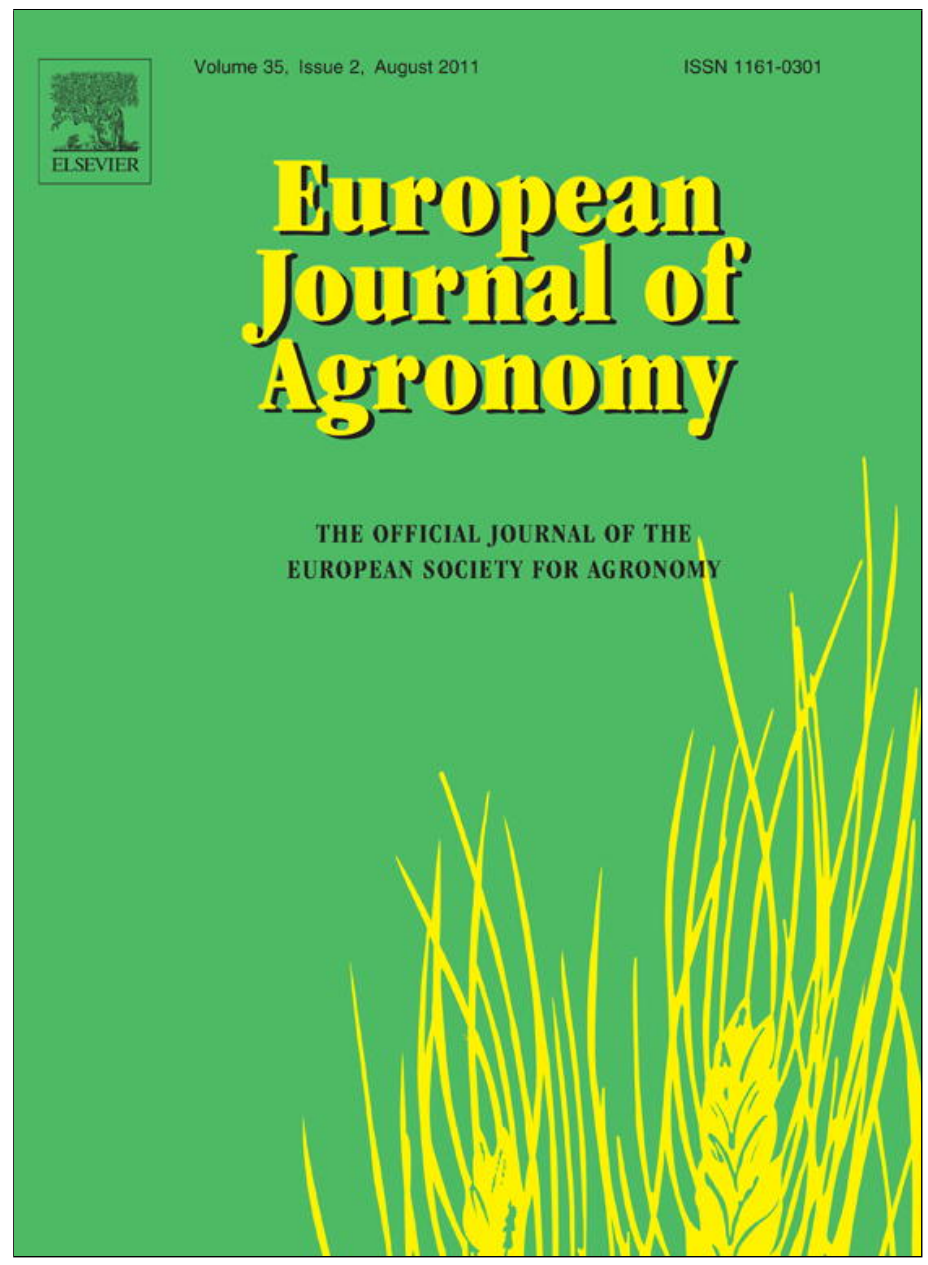

This article appeared in a journal published by Elsevier. The attached copy is furnished to the author for internal non-commercial research and education use, including for instruction at the authors institution and sharing with colleagues.

Other uses, including reproduction and distribution, or selling or licensing copies, or posting to personal, institutional or third party websites are prohibited.

In most cases authors are permitted to post their version of the article (e.g. in Word or Tex form) to their personal website or institutional repository. Authors requiring further information regarding Elsevier's archiving and manuscript policies are encouraged to visit:

http://www.elsevier.com/copyright 


\title{
Durum wheat grain yield and quality as affected by S rate under Mediterranean conditions
}

\author{
Laura Ercoli $^{\mathrm{a}, *}$, Leonardo Lulli $^{\mathrm{b}}$, Iduna Arduini ${ }^{\mathrm{b}}$, Marco Mariotti ${ }^{\mathrm{b}}$, Alessandro Masoni ${ }^{\mathrm{b}}$ \\ a Scuola Superiore Sant'Anna, p.zza Martiri della Libertà 33, 56127 Pisa, Italy \\ ${ }^{\mathrm{b}}$ Dipartimento di Agronomia e Gestione dell'Agroecosistema, via S. Michele degli Scalzi 2, 56124 Pisa, Italy
}

\section{A R T I C L E I N F O}

Article history:

Received 27 December 2010

Received in revised form 23 March 2011

Accepted 31 March 2011

\section{Keywords:}

Triticum durum

$\mathrm{N}$ fertilisation

$S$ fertilisation

Grain quality

\begin{abstract}
A B S T R A C T
The decreased inputs of $\mathrm{S}$ from atmospheric acidic deposition, the use of low S-containing fertilisers, and the decrease of organic matter content in soil resulted in S deficiency in many agricultural regions of the world. Sulphur fertilisation significantly affects grain yield and protein composition of cereals, thus altering the technological quality of grain. Field experiments were conducted in central Italy in two subsequent seasons to investigate the effects of $\mathrm{N}$ and $\mathrm{S}$ application on five commercial wheat cultivars known to differ in yield potential and grain $\mathrm{N}$ content. Fertiliser treatments were two levels of $\mathrm{N}$ fertiliser $\left(120 \mathrm{~kg} \mathrm{~N} \mathrm{ha}^{-1}\right.$ and $180 \mathrm{~kg} \mathrm{~N} \mathrm{ha}^{-1}$ ) and three levels of S fertiliser (not applied, $60 \mathrm{~kg} \mathrm{Sha}^{-1}$, and $120 \mathrm{~kg} \mathrm{Sha}^{-1}$ ). Analyzed characters were dry weight and $\mathrm{N}$ and $\mathrm{S}$ uptake of grain and vegetative plant part, and grain quality characters. Variations in weather pattern - and especially in rainfall - between years significantly influenced grain yield and $\mathrm{N}$ and $\mathrm{S}$ content of grain, but did not affect quality parameters. Nitrogen and $\mathrm{S}$ application also significantly affected grain yield and the quality characteristics $W, P / L$, dry gluten and SDS, although no interactive effect between treatments was observed. The highest protein content and $W$ in grain was obtained with the combination of the highest fertiliser rates: $180 \mathrm{~kg} \mathrm{~N} \mathrm{ha}^{-1}$ and $120 \mathrm{~kg} \mathrm{Sha}^{-1}$. Genotypes differed for yield stability between years, in that grain production was decreased in the driest year only in the varieties Claudio and Creso, but they responded similarly to $\mathrm{N}$ and $\mathrm{S}$ fertilisation. Genotypes differed also for protein concentration and quality parameters, and, on average, the varieties Duilio, Simeto and Svevo gave better performances. Differences in grain quality parameters were maintained through years, indicating that these traits are under strong genetic control.
\end{abstract}

(C) 2011 Elsevier B.V. All rights reserved.

\section{Introduction}

During the last decades, sulphur (S) deficiency in agricultural soils has become widespread in many European countries. This is mainly caused by the reductions in $\mathrm{SO}_{2}$ emissions, the use of low Scontaining fertilisers, the low $\mathrm{S}$ return with farmyard manure, and a declining use of S-containing fungicides (Schnug, 1991; de Ruiter and Martin, 2001; Scherer, 2001). It is expected that S deficiency will become even more common over the next decade, because $\mathrm{SO}_{2}$ emissions are likely to decrease further to accomplish international agreements on emissions.

The requirement of sulphur by wheat is not high, as the uptake is about $20 \mathrm{~kg} \mathrm{ha}^{-1}$ with a grain yield of $8 \mathrm{t} \mathrm{ha}^{-1}$ (McGrath et al., 1996). Nevertheless, deficiency has been documented in many cases and the effect of $S$ fertiliser is highly variable, ranging from 5 to $50 \%$ under field conditions (Zhao et al., 1999a). In Northcentral Oregon, McGrath et al. (1996) obtained little yield increase in response

\footnotetext{
* Corresponding author. Tel.: +39 050883357; fax: +39 050883215.

E-mail address: ercoli@sssup.it (L. Ercoli).
}

to S-application when wheat grain yields were below $2 \mathrm{t} \mathrm{ha}^{-1}$, but with higher yield, $27 \%$ of the 44 locations positively responded to $\mathrm{S}$ application. In field experiments with hard bread wheat in different regions of England, Zhao et al. (1999b) registered yield positive responses when S application was equal or lower than $20 \mathrm{~kg} \mathrm{Sha}^{-1}$, but loaf volume was significantly increased when the $S$ application rate was increased from 20 to $100 \mathrm{~kg} \mathrm{Sha}^{-1}$. de Ruiter and Martin (2001) concluded that $\mathrm{N}$ fertiliser strongly increased $\mathrm{N}$ uptake in vegetative parts and grain. By contrast, there was little effect of $S$ fertiliser on grain yield and grain $\mathrm{N}$ and $\mathrm{S}$ concentration and uptake.

For bread wheat (Triticum aestivum L.), apart from the effects on crop growth and grain yield, crop S nutrition can exert a large influence on the quality of wheat. Sulphur deficiency resulted in a decreased $\mathrm{S}$ amino acids content in grain and an accumulation of non-protein compounds such as amides, resulting in a $\mathrm{N}$ to $\mathrm{S}$ ratio greater than 15:1 (Stewart and Porter, 1969; Mortensen and Eriksen, 1994; Flæte et al., 2005). Furthermore, the technological properties of bread wheat are greatly affected by S deficiency (Randall and Wrigley, 1986; Zhao et al., 1999a). For example, S deficiency has been reported to produce doughs that are less extensible and loaves of smaller volume and poorer texture (Moss et al., 1981, 
1983; MacRitchie and Gupta, 1993; Zhao et al., 1999b). These deteriorations in rheological properties of doughs and in breadmaking quality of grain were associated with changes in the quantitative composition of gluten proteins (Wieser et al., 2004).

Less information is available concerning the influence of $\mathrm{S}$ status of durum wheat on the quality of grain and pasta. Grain quality derives mainly from quantity and specific composition of seed storage proteins, while the ability of semolina to form an ideal dough for pasta processing rests mainly on the rheological characteristics of its gluten, related to gluten elasticity or strength (D'Egidio et al., 1990). Work of Alary and Kobrehel (1987) showed a significant correlation between the total concentration of disulphide bonds in the glutenins and the cooking quality of pasta. Garrido-Lestache et al. (2005) found that neither soil application of sulphur-containing fertiliser nor leaf application of sulphur at ear emergence had any effect on durum quality indices, except for ash content, that increased with foliar application of sulphur. Conversely, in nonlimiting conditions for S-availability, Lerner et al. (2006) found that S-fertiliser application caused significant differences in grain protein concentration, SDS and N:S ratio, which, however, did not generate changes in rheological parameters and end-use of durum wheat.

Predicting $S$ availability to plants in field conditions has proved to be a difficult task, owing to different reasons. In soil, organic $S$ exists in numerous forms, that have different timescales for mineralization and mineralization only accounts for $0.5-3 \%$ per year of the soil organic S pool (Eriksen, 2009). The retention of sulphate in soil is weak and most of sulphate ions are in solution; thus agricultural soils are prone to sulphate leaching by percolating rainwater and sulphate leaching has been identified as the major $S$ output (Eriksen et al., 2002). Therefore, the uncertainties in the estimates of $\mathrm{S}$ delivery make a precise $\mathrm{S}$ fertilisation more difficult and crop response to $\mathrm{S}$ fertilisation often depends on the supply of $\mathrm{N}$ fertiliser (Moss et al., 1981; Timms et al., 1981). In addition, because of the strong inter-relationship between $\mathrm{N}$ and $\mathrm{S}$ nutrition, owing their involvement in the synthesis of structural proteins, deficiency of $\mathrm{S}$ may be induced by a high amount of applied $\mathrm{N}$ and responses to $\mathrm{S}$ application are usually greater when abundant amounts of $\mathrm{N}$ are applied (Zhao et al., 1999a; Lerner et al., 2006; Salvagiotti et al., 2009).

The aim of this study was to investigate the effect of combined $\mathrm{S}$ and $\mathrm{N}$ application on yield and grain quality of five durum wheat varieties, differing over grain yield and quality. Field experiments were carried out during two growing seasons under Mediterranean conditions and three levels of $S$ fertiliser were applied in combination with medium and high levels of nitrogen fertiliser. The data on grain $\mathrm{S}$ and $\mathrm{N}$ concentrations were combined over all treatments to examine the relationship between grain quality and $\mathrm{S}$ and $\mathrm{N}$ concentrations.

\section{Materials and methods}

\subsection{Location and experimental design}

Field experiments were carried out during two consecutive growing seasons (2003-2004 and 2004-2005) at the experimental station of the Department of Agronomy and Agroecosystem Management of the University of Pisa, Italy, that is located at a distance of approximately $10 \mathrm{~km}$ from the sea $\left(43^{\circ} 40^{\prime} \mathrm{N}, 10^{\circ} 19^{\prime} \mathrm{E}\right)$ and $1 \mathrm{~m}$ above sea level. The climate at the experimental site is cold, humid Mediterranean with mean annual maximum and minimum daily air temperatures of 20.2 and $9.5^{\circ} \mathrm{C}$, respectively, and precipitation of $971 \mathrm{~mm}$, with $688 \mathrm{~mm}$ received during the period of durum wheat cultivation, that is from November through July (Moonen et al., 2001). For both years, daily weather data were obtained from a
Table 1

Soil properties at the beginning of the 2003-2004 and 2004-2005 wheat growing seasons.

\begin{tabular}{llll}
\hline Parameter & Unit & \multicolumn{2}{l}{ Soil } \\
\cline { 3 - 4 } & & $2003-2004$ & $2004-2005$ \\
\hline Sand $(2 \mathrm{~mm}>\varnothing>0.05 \mathrm{~mm})$ & $\%$ & 57.8 & 53.7 \\
Silt $(0.05 \mathrm{~mm}>\emptyset>0.002 \mathrm{~mm})$ & $\%$ & 31.6 & 32.0 \\
Clay $(\varnothing<0.002 \mathrm{~mm})$ & $\%$ & 10.6 & 14.3 \\
pH & $\%$ & 8.2 & 8.3 \\
Organic matter & $\%$ & 1.6 & 1.5 \\
Total N & $\mathrm{g} \mathrm{kg}^{-1}$ & 1.0 & 0.9 \\
Available P & $\mathrm{mg} \mathrm{kg}^{-1}$ & 14.4 & 19.7 \\
Available K & $\mathrm{mg} \mathrm{kg}^{-1}$ & 70.5 & 69.2 \\
Total S & $\mathrm{g} \mathrm{kg}^{-1}$ & 0.31 & 0.32 \\
\hline
\end{tabular}

meteorological station located within $100 \mathrm{~m}$ from the experimental fields.

In both years the preceeding crop was berseem (Trifolium alexandrinum L.). Soil was ploughed at $40 \mathrm{~cm}$ depth in November and sowing was performed on 17 December 2003 and on 22 December 2004 at a rate of 400 viable seeds $\mathrm{m}^{-2}$.

Soil samples (0-40 cm depth) were collected in December 2003 and December 2004 before wheat seeding. Samples were air dried, ground, and analyzed for texture (hydrometer method), $\mathrm{pH}$ (saturated paste method), organic matter (Walkley and Black method), total N (Kjeldahl method), available P (Olsen method), available K (Dirks-Sheffer method) and total S (dry combustion and infrared detection, Schumacher et al., 1995) (Table 1). The soil type was sandy-loam according to the USDA classification. The fertiliser $S$ and $\mathrm{N}$ treatments, as well as the $\mathrm{P}$ and $\mathrm{K}$ rates were calculated based on the balance approach, which is considered a more reliable method than traditional soil tests to determine plant nutrient availability (Zhao et al., 1999b).

Experiments were set up in a split-split-plot design with three replications. In both years, five durum wheat (Triticum durum Desf.) varieties, Claudio, Creso, Duilio, Simeto and Svevo, were sown in each main plot. Within each main plot, subplots received two levels of $\mathrm{N}$ application, medium (120 kg N ha $\left.{ }^{-1}\right)$ and high $\left(180 \mathrm{~kg} \mathrm{~N} \mathrm{ha}^{-1}\right)$, hereafter referred to as N120 and N180, respectively. Sub-subplots received three levels of $S$ application, nil, high $\left(60 \mathrm{~kg} \mathrm{Sha}^{-1}\right)$ and very high $\left(120 \mathrm{~kg} \mathrm{Sha}^{-1}\right)$, hereafter referred to as S0, S60 and S120, respectively. Nitrogen was applied as urea, slitted into two (N120) or three (N180) applications of $60 \mathrm{~kg} \mathrm{~N} \mathrm{ha}^{-1}$, the first before seeding and the others at first node detectable (stage 31 of the scale of Zadoks et al., 1974) and 15 days after this stage. Sulphur was applied before seeding as calcium sulphate $\left(\mathrm{CaSO}_{4} \cdot 2 \mathrm{H}_{2} \mathrm{O}\right)$. Phosphorus and potassium were applied before seeding, as triple mineral phosphate and potassium chloride, at a rate of $100 \mathrm{~kg} \mathrm{ha}^{-1} \mathrm{P}_{2} \mathrm{O}_{5}$ and $\mathrm{K}_{2} \mathrm{O}$, respectively. The size of each sub-subplot was 4 by $6 \mathrm{~m}$ and consisted of 26 rows, each $6 \mathrm{~m}$ long, spaced at $0.15 \mathrm{~m}$. Weed control was performed at the stage of 4 th leaf unfolded (stage 14) by distributing a commercial graminicide.

Varieties of durum wheat were chosen to represent the high genotypic variability within durum wheat species. Comparisons of the performance of different varieties may be relevant considering the high spatial variability of the environmental conditions in the Mediterranean region. Creso and Duilio are old durum wheat varieties (released respectively in 1974 and 1984) that were widely cultivated in Central Italy in the past 20 years and are still in use. Both are characterized by a moderate but constant yield, medium grain quality, and a high adaptability to different environmental conditions. Simeto, Claudio and Svevo are more recent varieties characterized by taller size, higher productivity and improved protein content. 
Table 2

Results of the ANOVA on grain yield, yield components and N and S concentration and content in grain and vegetative plant part.

\begin{tabular}{|c|c|c|c|c|c|c|c|c|c|c|}
\hline $\begin{array}{l}\text { Source of } \\
\text { variation }\end{array}$ & $\begin{array}{l}\text { Grain } \\
\text { yield }\end{array}$ & $\begin{array}{l}\text { Vegetative } \\
\text { plant part }\end{array}$ & $\mathrm{HI}$ & $\begin{array}{l}\text { Mean } \\
\text { kernel } \\
\text { weight }\end{array}$ & $\begin{array}{l}\text { No. } \\
\text { spikes m }^{-2}\end{array}$ & $\begin{array}{l}\text { No. } \\
\text { kernels spike }{ }^{-1}\end{array}$ & $\begin{array}{l}\text { Grain N } \\
\text { concentration }\end{array}$ & $\begin{array}{l}\text { Vegetative } \mathrm{N} \\
\text { concentration }\end{array}$ & $\begin{array}{l}\text { Grain S } \\
\text { concentration }\end{array}$ & $\begin{array}{l}\text { Vegetative S } \\
\text { concentration }\end{array}$ \\
\hline $\operatorname{Year}(\mathrm{Y})$ & * & * & n.s. & n.s. & * & * & n.s. & n.s. & n.s. & n.s. \\
\hline Variety (V) & * & * & n.s. & n.s. & * & * & * & ${ }^{*}$ & n.s. & n.s. \\
\hline $\mathrm{N}$ rate $(\mathrm{N})$ & * & * & n.s. & $*$ & * & n.s. & * & * & n.s. & n.s. \\
\hline$S$ rate $(S)$ & $*$ & * & n.s. & n.s. & n.s. & & n.s. & n.s. & & ${ }^{*}$ \\
\hline $\mathrm{Y} \times \mathrm{V}$ & * & * & n.s. & n.s. & * & * & n.s. & n.s. & n.s. & n.s. \\
\hline $\mathrm{Y} \times \mathrm{N}$ & n.s. & * & n.s. & n.s. & n.s. & n.s. & n.s. & n.s. & n.s. & n.s. \\
\hline $\mathrm{Y} \times \mathrm{S}$ & $*$ & * & n.s. & n.s. & n.s. & n.s. & n.s. & n.s. & n.s. & n.s. \\
\hline $\mathrm{V} \times \mathrm{N}$ & n.s. & n.s. & n.s. & n.s. & n.s. & n.s. & n.s. & n.s. & n.s. & n.s. \\
\hline $\mathrm{V} \times \mathrm{S}$ & n.s. & n.s. & n.s. & n.s. & n.s. & n.s. & n.s. & n.s. & n.s. & n.s. \\
\hline $\mathrm{N} \times \mathrm{S}$ & n.s. & n.s. & n.s. & n.s. & n.s. & n.s. & n.s. & n.s. & n.s. & n.s. \\
\hline
\end{tabular}

n.s., not significant.

Significant at $P<0.05$.

\subsection{Sampling and analytical procedures}

At physiological maturity (stage 90), plants from four adjacent rows of $1 \mathrm{~m}$ length, corresponding to a $0.6 \mathrm{~m}^{2}$ area per plot, were manually cut at ground level and were separated into culms, leaves, chaff and grain. For dry weight determination, samples from all plant parts were oven dried at $65^{\circ} \mathrm{C}$ to constant weight. The number of ears was counted and the mean kernel dry weight determined, and the number of kernels per unit area was calculated. Samples of each plant part were analyzed for nitrogen (Kjeldahl method) and sulphur (dry combustion and infrared detection, Schumacher et al., 1995) concentrations; $\mathrm{N}$ and $\mathrm{S}$ contents were calculated by multiplying $\mathrm{N}$ or $\mathrm{S}$ concentration by dry weight. Since the effects of treatments were similar on leaves, culms and chaff, data were combined together and hereafter referred as vegetative plant part. Grains were milled to flour using a Labormill 4RB. Dry gluten concentration was determined using the Glutomatic system, following the standard method ICC no. 137 (ICC, 1986). Gluten index was determined using the Glutomatic system, following the standard method ICC no. 155. The test of SDS-sedimentation (height of sediment in $\mathrm{mm}$ ) was performed according to Dick and Quick (1983). Alveographic tests were performed using the ICC method no. 121. Three alveographic indices were recorded for each sample: $P$ that corresponds to the height $(\mathrm{mm})$ of the alveograph curve and is related to the tenacity of dough; $L$ that corresponds to the length of the alveograph curve ( $\mathrm{mm}$ ) and is an index of dough extensibility; $W\left(J \times 10^{-4}\right)$ that corresponds to the total area of the alveograph curve and is related to the strength of the dough. The ratio $P / L$ was also calculated. Pasta value (PV) was calculated by the method described by Landi (1995) as follows:

$\mathrm{PV}=K+2 \mathrm{GLU}+0.04 W+8.5\left(\frac{P}{L}\right)-2\left(\frac{P}{L}\right)^{2}$

where GLU = dry gluten (\%) and $K$ is a numerical factor depending on the temperature in the drying cycle used in pasta production; in drying cycles at $80-85^{\circ} \mathrm{C} K$ is 42 . Pasta values range from 0 to 100 points, a good quality pasta having a minimum of 80 points.

\subsection{Statistical analysis}

Data were statistically treated by ANOVA, in order to test the main effects of year, variety, $\mathrm{N}$ rate, $\mathrm{S}$ rate and their interactions. Significantly different means were separated at the 0.05 probability level by the least significant difference test (Steel et al., 1997).

\section{Results}

\subsection{Yield and yield components}

Treatments differently affected all measured parameters (Table 2). Third and fourth order interactions were never significant, while second order interactions were significant only for year $\times$ variety and year $\times S$ rate. Total rainfall during wheat growing season differed between years, in that it was $622 \mathrm{~mm}$ in 2003-2004 and $376 \mathrm{~mm}$ in 2004-2005, although during grain filling values were similar (122 mm in 2003-2004 and $78 \mathrm{~mm}$ in 2004-2005). Differences in rainfall between the two growing seasons are likely to account for the significant year $\times$ treatment interaction effects. Conversely, in both seasons mean temperatures were similar to the normal temperature (Fig. 1).

Grain yield did non change significantly between years in the varieties Svevo, Duilio and Simeto that produced, in the order, approximately 4.3, 4.6 and $4.8 \mathrm{tha}^{-1}$ (Table 3 ). By contrast, in the other two varieties grain yield was by $9-16 \%$ lower in 2005 compared to 2004, decreasing from 4.8 to $4.1 \mathrm{tha}^{-1}$ in Claudio and from 4.5 to $3.7 \mathrm{tha}^{-1}$ in Creso.

Yield components were differently sensitive to climatic variations between years and changed with different patterns among varieties. Indeed, the number of spikes per unit area and the number of kernels per spike were significantly affected by the interaction $\mathrm{Y} \times \mathrm{V}$, whereas mean kernel weight did not (Table 2). Spike number per unit area did not vary between years with the exception of Duilio, which had a value by $21 \%$ higher in 2004 than in 2005 (Table 3 ). Number of kernels per spike did not vary appreciably between years in the varieties Claudio, Simeto and Svevo. By contrast, in Creso it was by $25 \%$ lower in 2005 compared to 2004 , and in Duilio it was by $15 \%$ higher (Table 3 ).

Nitrogen fertilisation significantly affected dry weight of grain, which increased by $19 \%$ with the increase of N rate from N120 to N180, irrespective of year, variety and S rate (Table 4). Yield components were also differently affected by $\mathrm{N}$ rate. Both mean kernel weight and number of spikes per unit area were increased by $11 \%$ with high $\mathrm{N}$ fertilisation rate, whereas the number of kernels per spike was not affected (Table 4).

Sulphur fertilisation increased grain yield in 2004, but did not modify it in 2005. Averaged over varieties and $\mathrm{N}$ rates, grain yield increased up to $14 \%$ compared to the $S$ unfertilised control in 2004 (Fig. 2A). The effect of $S$ fertilisation on grain yield was essentially due to the higher number of kernels per spike, which increased by $10 \%$ at the highest $\mathrm{S}$ rate (Fig. $2 \mathrm{~B}$ ).

Similarly to grain yield, dry weight of vegetative plant part was by $13-19 \%$ lower in 2005 than in 2004 in all varieties but Simeto, that produced equivalent amounts in both years (Table 3 ). The dry weight of vegetative plant part was positively affected by nitrogen 
Table 3

Grain yield, vegetative dry weight, number of spikes $/ \mathrm{m}^{2}$ and number of kernels per spike. Year $\times$ variety interaction.

\begin{tabular}{|c|c|c|c|c|c|}
\hline Year & Variety & Grain yield $\left(\mathrm{tha}^{-1}\right)$ & Vegetative d.w. $\left(\right.$ tha $\left.^{-1}\right)$ & Spike number $\left(\mathrm{n} \mathrm{m}^{-2}\right)$ & Kernel number (n. spike ${ }^{-1}$ ) \\
\hline \multirow[t]{5}{*}{2004} & Claudio & $4.8 \mathrm{~d}$ & $6.5 c$ & 407.8ab & $25.9 a$ \\
\hline & Creso & $4.5 \mathrm{bcd}$ & $6.4 \mathrm{c}$ & 408.2ab & $25.1 \mathrm{ab}$ \\
\hline & Duilio & $4.6 \mathrm{~d}$ & $6.6 c$ & $488.7 d$ & $21.7 \mathrm{~cd}$ \\
\hline & Simeto & $4.8 \mathrm{~d}$ & $6.7 c$ & $455.8 \mathrm{~cd}$ & $23.5 a b c$ \\
\hline & Svevo & $4.5 \mathrm{~cd}$ & $6.6 c$ & $431.2 b c$ & $23.4 \mathrm{abc}$ \\
\hline \multirow[t]{5}{*}{2005} & Claudio & $4.1 \mathrm{ab}$ & $5.8 \mathrm{ab}$ & $371.4 a$ & 23.9abc \\
\hline & Creso & $3.7 \mathrm{a}$ & $5.6 a$ & 412.4abc & $20.1 d$ \\
\hline & Duilio & $4.5 \mathrm{~cd}$ & $5.6 a$ & $404.4 \mathrm{ab}$ & $25.0 \mathrm{ab}$ \\
\hline & Simeto & $4.8 \mathrm{~d}$ & $6.3 b c$ & $413.0 \mathrm{abc}$ & $25.1 \mathrm{ab}$ \\
\hline & Svevo & $4.1 \mathrm{bc}$ & $5.6 a$ & 408.8ab & $22.2 \mathrm{bcd}$ \\
\hline
\end{tabular}

Within columns, numbers followed by the same letter are not significantly different at $P<0.05$.

Table 4

Grain yield, vegetative dry weight and number of spikes per unit area, number of kernels per spike and mean kernel weight. Nitrogen rate mean values.

\begin{tabular}{lllll}
\hline Treatment & Grain yield $\left(\mathrm{t} \mathrm{ha}^{-1}\right)$ & Vegetative d.w. $\left(\mathrm{t} \mathrm{ha}^{-1}\right)$ & Spike number $\left(\mathrm{n} \mathrm{m}^{-2}\right)$ & Kernel number $\left(\mathrm{n}\right.$. spike $\left.{ }^{-1}\right)$ \\
\hline N rate & & & & \\
N120 & $4.0 \mathrm{a}$ & $5.5 \mathrm{a}$ & $398.4 \mathrm{a}$ & $24.0 \mathrm{a}$ \\
$\mathrm{N} 180$ & $4.8 \mathrm{~b}$ & $6.8 \mathrm{~b}$ & $441.9 \mathrm{~b}$ & $23.2 \mathrm{a}$
\end{tabular}

Within columns, numbers followed by the same letter are not significantly different at $P<0.05$.

and, irrespective of the cultivation year, it increased by $24 \%$ with the increase of $\mathrm{N}$ rate (Table 4). Conversely, vegetative biomass was increased up to $20 \%$ with the increase of S rate in 2004 , while it was not modified in 2005 (Fig. 2C). Finally, harvest index was not
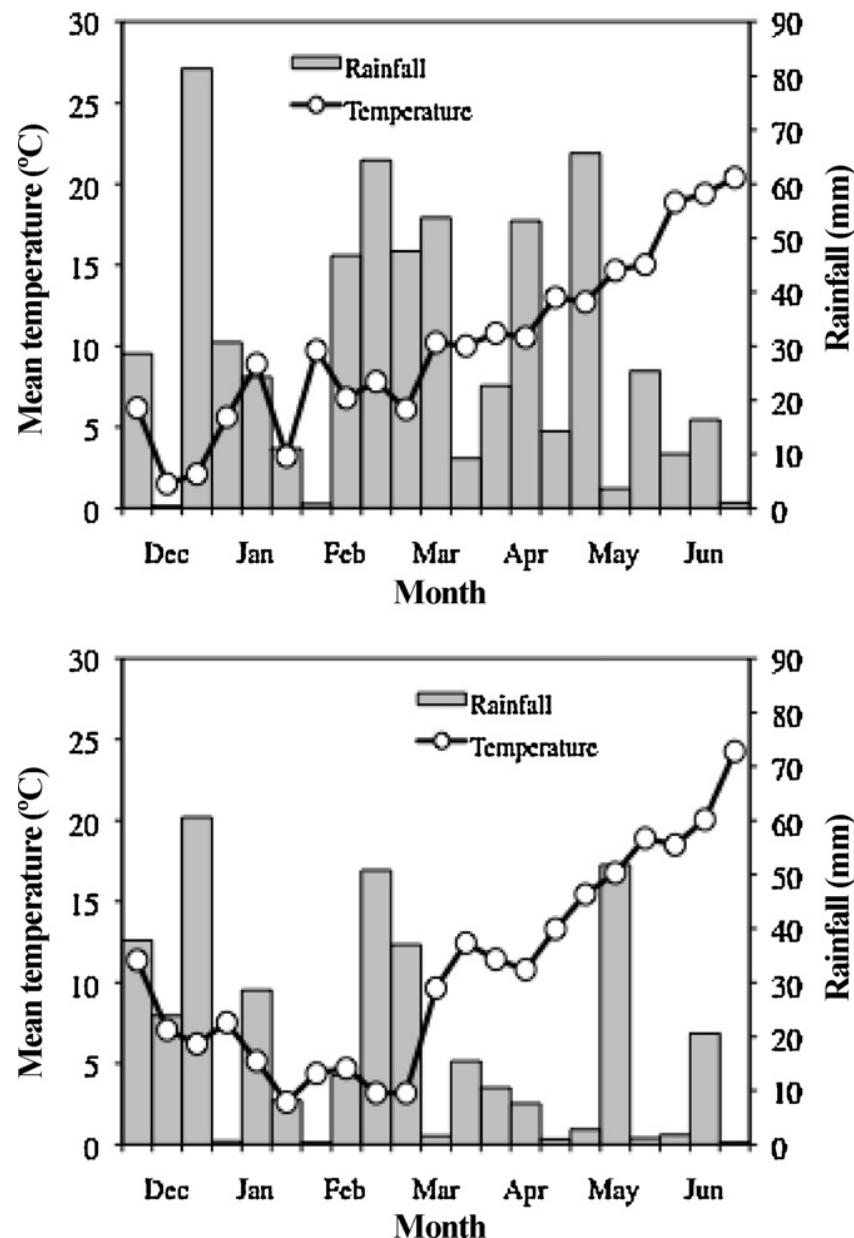

Fig. 1. Rainfall and temperature during 2003-2004 (up) and 2004-2005 (down) wheat growing season.
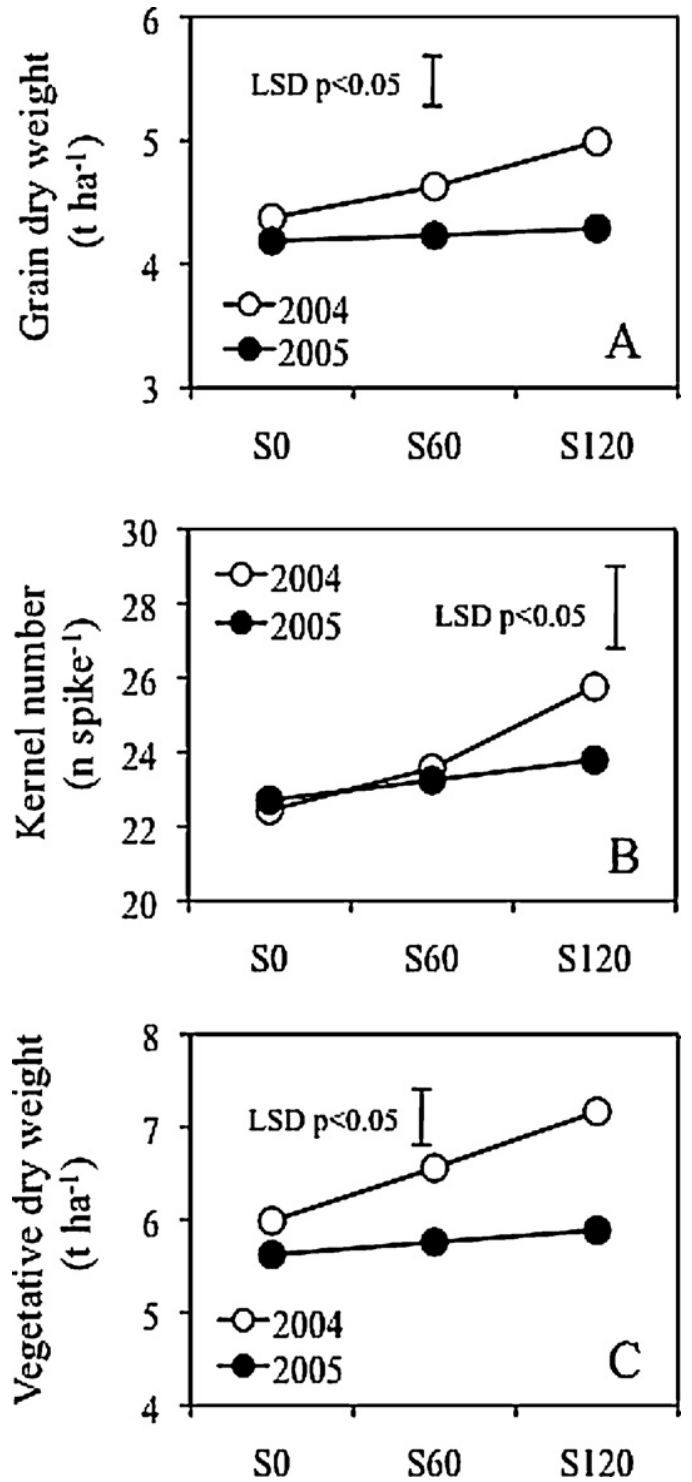

Fig. 2. Grain dry weight (A), number of kernels per spike (B), and vegetative dry weight $(C)$ as affected by year $\times$ sulphur rate interaction. 
Table 5

Sulphur concentration in grain and vegetative plant part. Sulphur rate mean values.

\begin{tabular}{cll}
\hline Treatment & $\begin{array}{l}\text { Grain S } \\
\text { concentration } \\
\left(\mathrm{g} \mathrm{kg}^{-1}\right)\end{array}$ & $\begin{array}{l}\text { Vegetative } S \\
\text { concentration } \\
\left(\mathrm{g} \mathrm{kg}^{-1}\right)\end{array}$ \\
\hline S rate & \\
S0 & $1.4 \mathrm{a}$ & $1.5 \mathrm{a}$ \\
S60 & $1.5 \mathrm{~b}$ & $1.6 \mathrm{~b}$ \\
S120 & $1.6 \mathrm{c}$ & $1.7 \mathrm{c}$ \\
\hline
\end{tabular}

Within each column, numbers followed by the same letter are not significantly different at $P<0.05$.

affected by any treatment and, averaged over years, varieties, and $\mathrm{N}$ and $\mathrm{S}$ rates, it was $42 \%$ (results not shown).

\subsection{Sulphur concentration}

Sulphur concentration of grain and vegetative plant part were not affected by year, variety and $\mathrm{N}$ rate but responded significantly to $S$ rate, increasing with rising S levels (Table 2). Compared to controls without $S$, the increase in grain was by $10 \%$ with $S 60$ and by $15 \%$ with $\mathrm{S} 120$, whereas in vegetative plant parts it was by $5 \%$ and $10 \%$, respectively (Table 5 ).

In our research, plotting $\mathrm{N}$ against $\mathrm{S}$ concentrations in grain we observed that 43 out of 60 data points lied within the lines 15:1 and 12:1 (Fig. 3) and only 2 data points lied over the $17: 1$ limit. These points refer to Creso fertilised with SO in both years of cultivation. In addition, $\mathrm{S}$ concentration of grain was higher than the threshold $1.2 \mathrm{mg} \mathrm{S} \mathrm{g}^{-1}$ in all treatments, indicating that in our experiment grain was not $\mathrm{S}$ deficient according to these criteria. This is also confirmed by the lack of visual symptoms of S deficiency.

\subsection{Nitrogen concentration}

The $\mathrm{N}$ concentration of grain and vegetative plant part were neither significantly affected by the year and $\mathrm{S}$ rate mean effects nor by the interactions between years, varieties and $\mathrm{N}$ and $\mathrm{S}$ treatments (Table 2). Therefore, only the means for the five varieties and the two $\mathrm{N}$ treatments were shown in Table 6 . Nitrogen concentration of grain differed among varieties and increased with the increase of $\mathrm{N}$ rate. Higher $\mathrm{N}$ concentrations were found in Svevo, Simeto and Creso (22-23 $\mathrm{g} \mathrm{kg}^{-1}$ ), while Claudio and Duilio had lower values $\left(20 \mathrm{~g} \mathrm{~kg}^{-1}\right)$. Averaged over varieties, $\mathrm{N}$ concentration in grain increased by $13 \%$ with $\mathrm{N} 180$. Nitrogen concentration in vegetative plant part also varied among varieties and was increased by $\mathrm{N}$ rate: it was by $18 \%$ higher in Creso compared to Claudio and Svevo,

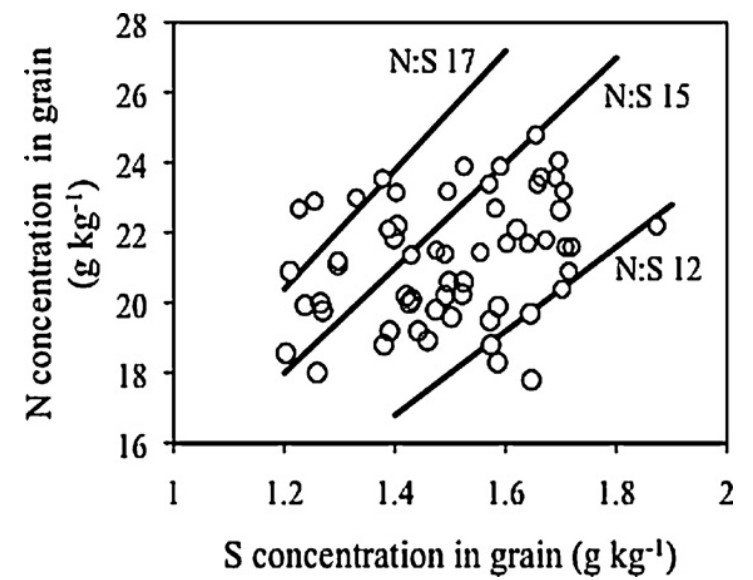

Fig. 3. Correlation between $\mathrm{N}$ and $\mathrm{S}$ concentration in grain. Lines indicate critical $\mathrm{N}: \mathrm{S}$ ratios (see text for references).
Table 6

Nitrogen concentration in grain and vegetative plant part. Variety and $\mathrm{N}$ rate mean values.

\begin{tabular}{lll}
\hline Treatments & $\begin{array}{l}\text { Grain } \mathrm{N} \\
\text { concentration } \\
\left(\mathrm{g} \mathrm{kg}^{-1}\right)\end{array}$ & $\begin{array}{l}\text { Vegetative } \mathrm{N} \\
\text { concentration } \\
\left(\mathrm{g} \mathrm{kg}^{-1}\right)\end{array}$ \\
\hline Variety & $20.2 \mathrm{a}$ & $5.3 \mathrm{a}$ \\
$\quad$ Claudio & $21.8 \mathrm{~b}$ & $6.4 \mathrm{c}$ \\
Creso & $20.4 \mathrm{a}$ & $5.8 \mathrm{~b}$ \\
Duilio & $21.8 \mathrm{~b}$ & $5.8 \mathrm{~b}$ \\
Simeto & $22.6 \mathrm{~b}$ & $5.5 \mathrm{a}$ \\
Svevo & & \\
N rate & $19.9 \mathrm{a}$ & $5.3 \mathrm{a}$ \\
N120 & $22.5 \mathrm{~b}$ & $6.1 \mathrm{~b}$ \\
N180 & &
\end{tabular}

Within treatments variety and $\mathrm{N}$ rate, numbers followed by the same letter are not significantly different at $P<0.05$.

whereas Duilio and Simeto had intermediate values. Finally, the higher $\mathrm{N}$ rate increased $\mathrm{N}$ concentration in the vegetative part by $15 \%$ (Table 6).

\subsection{Quality characteristics of grain}

In the present research, quality parameters of grain showed considerable variation, as would be expected from a diverse collection of genotypes fertilised with different $\mathrm{N}$ and $\mathrm{S}$ rates. Interactions among treatments were not statistically significant for all quality parameters except $P / L$, which showed a significant $\mathrm{V} \times \mathrm{S}$ interaction (Table 7). Year mean effect was never significant, variety mean effect was significant for alveograph $W$ and $P / L$ and for gluten index, $\mathrm{N}$ rate was significant for alveograph $W$, dry gluten concentration, gluten index and SDS. Finally, $S$ rate was significant for all measured parameters.

Averaged over year and $\mathrm{N}$ and $\mathrm{S}$ rates, alveograph $W$ was highest in Simeto, intermediate in Duilio and Svevo, and lowest in Claudio and Creso (Table 8). Gluten index also differed among varieties, as it was highest in Claudio and Svevo, intermediate in Creso and Simeto, and lowest in Duilio (Table 8). Conversely, varieties did not differ in dry gluten concentration, SDS and PV.

All measured quality parameters, except PV, significantly increased with the increase of $\mathrm{N}$ rate (Table 8). Alveograph $W$ and dry gluten increased by $8 \%$, gluten index by $6 \%$ and SDS by $13 \%$. Sulphur fertilisation also positively affected all quality parameters. Alveograph $W$ and dry gluten progressively increased with the increase of S rate up to $18 \%$ and $19 \%$ respectively (Table 8 ). Conversely, the other parameters increased significantly in response to sulphur application without differences between $S$ rates. The increase was by $6 \%, 10 \%$ and $6 \%$ for gluten index, SDS and PV, respectively.

The response of alveograph $P / L$ to $S$ application differed among varieties (Fig. 4). At SO $P / L$ was higher in Simeto and then decreased in the following order: Creso $=$ Duilio $>$ Claudio $=$ Svevo . Sulphur fer tilisation did not affect $P / L$ of Claudio, Creso and Svevo, while it decreased by $20 \%$ those of Duilio and Simeto. The different responses to $S$ fertilisation, however, did not change ranking of varieties at both $\mathrm{S}$ rates.

\subsection{Correlations between quality characteristics of grain and $N$ and $S$ concentration}

Relationships between grain quality parameters and $\mathrm{N}$ and $\mathrm{S}$ concentration were explored through correlation analysis (Table 9). All quality characters tested in this experiment were significantly correlated to both $\mathrm{N}$ and $\mathrm{S}$ concentration of grain, with the only exception of $P / L$ with $\mathrm{N}$ concentration. However, any given quality character was correlated more closely with $\mathrm{S}$ concentration than 
Table 7

Results of the ANOVA on grain quality characters.

\begin{tabular}{|c|c|c|c|c|c|c|}
\hline Source of variation & Alveograph $W$ & Alveograph $P / L$ & Dry gluten concentration & Gluten index & SDS test & PV \\
\hline Y & n.s. & n.s. & n.s. & n.s. & n.s. & n.s. \\
\hline V & * & * & n.s. & * & n.s. & n.s. \\
\hline $\mathrm{N}$ & * & n.s. & ${ }^{*}$ & * & ${ }^{*}$ & n.s. \\
\hline $\mathrm{S}$ & * & $*$ & ${ }^{*}$ & * & * & $*$ \\
\hline $\mathrm{Y} \times \mathrm{V}$ & n.s. & n.s. & n.s. & n.s. & n.s. & n.s. \\
\hline $\mathrm{Y} \times \mathrm{N}$ & n.s. & n.s. & n.s. & n.s. & n.s. & n.s. \\
\hline $\mathrm{Y} \times \mathrm{S}$ & n.s. & n.s. & n.s. & n.s. & n.s. & n.s. \\
\hline $\mathrm{V} \times \mathrm{N}$ & n.s. & n.s. & n.s. & n.s. & n.s. & n.s. \\
\hline $\mathrm{V} \times \mathrm{S}$ & n.s. & * & n.s. & n.s. & n.s. & n.s. \\
\hline $\mathrm{N} \times \mathrm{S}$ & n.s. & n.s. & n.s. & n.s. & n.s. & n.s. \\
\hline
\end{tabular}

n.s., not significant.

Significant at $P<0.05$.

Table 8

Quality characteristics of grain. Variety, N and S rates mean values.

\begin{tabular}{|c|c|c|c|c|c|}
\hline Treatments & Alveograph $W\left(J \times 10^{-4}\right)$ & Dry gluten (\%) & Gluten index & $\mathrm{SDS}(\mathrm{mm})$ & PV \\
\hline \multicolumn{6}{|l|}{ Variety } \\
\hline Claudio & $201.2 \mathrm{a}$ & $10.1 \mathrm{a}$ & $77.2 \mathrm{a}$ & $35.8 \mathrm{a}$ & 77.9a \\
\hline Creso & $192.3 a$ & $10.4 a$ & $74.1 \mathrm{ab}$ & $34.9 a$ & $79.0 \mathrm{a}$ \\
\hline Duilio & $204.7 \mathrm{ab}$ & $9.9 a$ & $72.7 \mathrm{~b}$ & $35.3 a$ & $78.8 a$ \\
\hline Simeto & $225.5 b$ & $10.4 a$ & 75.7ab & $36.4 a$ & $78.7 a$ \\
\hline Svevo & 213.9ab & $10.4 a$ & 77.9a & $37.5 \mathrm{a}$ & $79.2 \mathrm{a}$ \\
\hline \multicolumn{6}{|l|}{$\mathrm{N}$ rate } \\
\hline N120 & $200.7 a$ & $9.2 \mathrm{a}$ & $73.4 a$ & $33.8 \mathrm{a}$ & $77.7 a$ \\
\hline N180 & $215.0 \mathrm{~b}$ & $10.6 b$ & $77.6 \mathrm{~b}$ & $38.2 \mathrm{~b}$ & $79.7 a$ \\
\hline \multicolumn{6}{|l|}{ S rate } \\
\hline so & 188.6a & $9.2 \mathrm{a}$ & $72.2 \mathrm{a}$ & $33.4 \mathrm{a}$ & $75.9 a$ \\
\hline S60 & $211.7 \mathrm{~b}$ & 10.6ab & $76.7 \mathrm{~b}$ & $36.8 b$ & $79.7 b$ \\
\hline S120 & $222.4 \mathrm{c}$ & $10.9 \mathrm{~b}$ & $77.6 \mathrm{~b}$ & $37.8 \mathrm{~b}$ & $80.6 b$ \\
\hline
\end{tabular}

Within treatments $\mathrm{N}$ rate and $\mathrm{S}$ rate, numbers followed by the same letter are not significantly different at $P<0.05$.

Table 9

Correlation coefficients $(r)$ between grain $\mathrm{N}$ and S concentration and grain quality characters.

\begin{tabular}{|c|c|c|c|c|c|c|c|c|}
\hline & $\% \mathrm{~N}$ & $\% \mathrm{~S}$ & W & $P / L$ & Dry gluten & Gluten index & SDS & PV \\
\hline$\% \mathrm{~N}$ & 1.00 & & & & & & & \\
\hline$\% \mathrm{~S}$ & $0.28^{*}$ & 1.00 & & & & & & \\
\hline$W$ & $0.40^{* *}$ & $0.65^{* *}$ & 1.00 & & & & & \\
\hline$P / L$ & 0.02 & $0.25^{*}$ & 0.05 & 1.00 & & & & \\
\hline Dry gluten & $0.46^{* *}$ & $0.55^{* *}$ & $0.66^{* *}$ & 0.19 & 1.00 & & & \\
\hline Gluten index & $0.31^{*}$ & $0.53^{* *}$ & $0.43^{* *}$ & $0.43^{* *}$ & $0.63^{* *}$ & 1.00 & & \\
\hline SDS & $0.62^{* *}$ & $0.65^{* *}$ & $0.74^{* *}$ & 0.23 & $0.76^{* *}$ & $0.57^{* *}$ & 1.00 & \\
\hline PV & $0.42^{* *}$ & $0.59^{* *}$ & $0.71^{* *}$ & $0.26^{* *}$ & $0.89^{* *}$ & $0.59^{* *}$ & $0.73^{* *}$ & 1.00 \\
\hline
\end{tabular}

Significance levels: $P<0.05$

Significance levels: $P<0.01$.

with $\mathrm{N}$ concentration. SDS was the quality parameter that correlated most strongly with both $\mathrm{N}$ and $\mathrm{S}$ grain concentration. In addition, alveograph $W$ showed a high correlation with $S$ concentration. Correlation between grain $\mathrm{N}$ and $\mathrm{S}$ concentration, on the

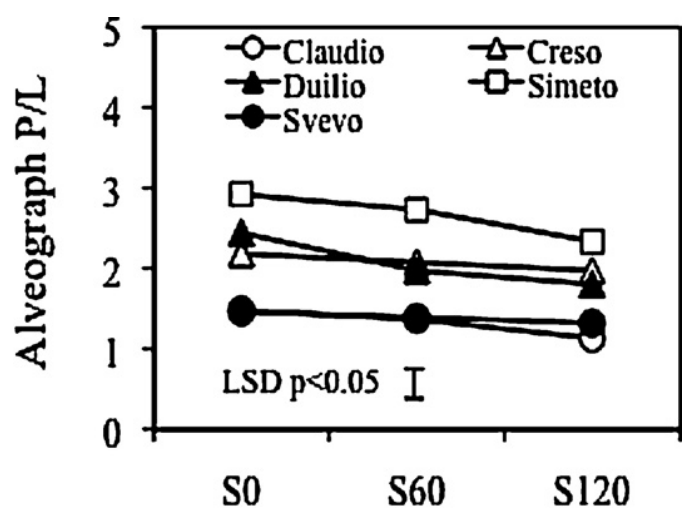

Fig. 4. Alveograph $P / L$ of grain as affected by variety $\times$ sulphur rate interaction. contrary, was low, and this is confirmed by the wide variation of the $\mathrm{N} / \mathrm{S}$ ratio in grain, ranging from 10.8 to 18.5 .

\section{Discussion}

The results obtained in this study demonstrate that $\mathrm{N}$ and $\mathrm{S}$ fertiliser treatments have marked effects on grain yield and quality of durum wheat. Grain yield increased up to $4.8 \mathrm{tha}^{-1}$ in response to the increase of $\mathrm{N}$ fertilisation from 120 to $180 \mathrm{~kg} \mathrm{~N} \mathrm{ha}^{-1}$, owing to the increase of both mean kernel weight and number of spikes per unit area, whereas the number of kernels per spike was not affected. Grain yield response to $\mathrm{N}$ fertilisation was similar to that reported by Ercoli et al. (2008) with the same $\mathrm{N}$ rates and environmental conditions, indicating that the crop fertilised with $120 \mathrm{~kg} \mathrm{Nha}^{-1}$ had less than optimal soil $\mathrm{N}$ availability for growth. Sulphur fertilisation increased grain yield only in the wetter year, and this effect is likely to depend to the leaching losses of S owing to high winter rainfall. In the drier year, probably, water stress decreased crop growth and consequently $\mathrm{S}$ demand, so that mineralised soil organic S was sufficient to fulfil S requirement of plants. The pos- 
itive effect of sulphur fertilisation on grain yield was essentially due to the higher number of kernels per spike, which could be due to a stimulation of the initiation of spikelets and/or florets, or of a reduction the mortality of florets (Archer, 1974; Monaghan et al., 1997). The lack of response to $S$ fertiliser we found for the other yield components, number of spikes and mean kernel weight, suggests that plants were not under severe S deficiency (Zhao et al., 1999a).

Grain yield and biomass production of the tested varieties responded similarly to $\mathrm{N}$ and $\mathrm{S}$ fertilisation, but were differently sensitive to year-on-year variations in the amount of rainfall during the wheat growing season. The varieties Claudio and Creso were sensitive to water shortage, which reduced the number of both spikes per unit area and kernels per spike in Claudio, and only the number of kernels per spike in Creso. Conversely, grain yield of the other three varieties did not change between years. In the variety Duilio, this was due to a compensation mechanism, since in the drier year the lower number of spikes per unit area was counterbalanced by a higher number of kernels per spike, while in Simeto and Svevo no yield component was affected. The contrasting response of varieties to environmental fluctuations is of high concern in Mediterranean environments, as the high variability in rainfall is a typical feature of this region.

Nitrogen application had a positive effect on grain $\mathrm{N}$ concentration and genotypic differences in the capacity to accumulate $\mathrm{N}$ in grain were also evidenced in this trial. Conversely, S concentration in grain was not under genetic control, was modified by $\mathrm{S}$ fertilisation and was unaffected by $\mathrm{N}$ fertilisation. We are not able to quantify the relationship between $S$ concentration in grain and the plant S status. To our knowledge no thresholds are available in literature for the diagnosis of S deficiency in durum wheat. For bread wheat, Randall et al. (1981) proposed grain S concentration and grain $\mathrm{N}: \mathrm{S}$ ratio to diagnose $\mathrm{S}$ deficiency, with critical values set, respectively, lower than $1.2 \mathrm{mg} \mathrm{Sg}^{-1} \mathrm{~d} . \mathrm{w}$. and higher than 17:1. According to above criteria, grain was not $\mathrm{S}$ deficient in our research, which is also confirmed by the lack of visual symptoms of $\mathrm{S}$ deficiency in plants. However, the variation in the ratio $\mathrm{N} / \mathrm{S}$ due to $\mathrm{S}$ application suggests an increase of the proportion of S-rich proteins to S-poor ones, as reported by Zhao et al. (1999a) and Wieser et al. (2004). These compositional changes in bread wheat were associated with rheological changes of the dough, giving increased resistance and decreased extensibility (Flæte et al., 2005).

Grain protein concentration is an important quality parameter for durum wheat, as it is widely used as a criterion in determining premium prices. It can be estimated multiplying nitrogen concentration in grain by the conversion factor 5.7. Grain protein concentrations obtained in this experiment ranged from $11.5 \%$ to $12.8 \%$, with the lowest values recorded in Claudio and Duilio and the highest in Svevo, and was not appreciably modified by $S$ fertilisation. The UNI EN ISO 9001 quality management system indicates $11.5 \%$ as lower limit for class 3 grain. It is worth mention that this threshold was exceeded in the majority of samples ( 42 out of 60 ) in the present research. The Barilla Pasta Company, one of the most important producer of pasta in the world, set a higher threshold $(12 \%)$ in the crop contract with farmers for the reception of grain. According to present results, $\mathrm{N}$ fertilisation at $180 \mathrm{~kg} \mathrm{~N} \mathrm{ha}^{-1}$ would be necessary to accomplish to this limit.

Nitrogen and sulphur fertiliser treatments had marked effects on quality characters of the tested varieties. The increase of $\mathrm{N}$ rate from 120 to $180 \mathrm{~kg} \mathrm{~N} \mathrm{ha}^{-1}$ improved most of the quality parameters determined in this research, as the effect of $\mathrm{N}$ fertilisation was significant for alveograph $W$, dry gluten concentration, gluten index and SDS. Sulphur fertilisation also improved grain quality and the effect was significant for all measured rheological and technologic parameters. Assessing the overall quality of durum wheat grain for the production of pasta is a difficult task, since it includes quality parameters of grain, dough and pasta, that are evaluated by many chemical and rheological tests as well as sensory analysis, whose results are often conflicting (Kovacs et al., 1997). Grain quality derives mainly from quantity and specific composition of seed storage proteins, while the ability of semolina to form an ideal dough for pasta processing rests mainly on the rheological characteristics of its gluten, elasticity or strength (D'Egidio et al., 1990). Following the Research Department of the Barilla Pasta Company, the pasta-making quality of grain derives mainly from high protein content and high gluten strength and elasticity (Landi, 1995). Acceptable pasta quality must have $W>150, P / L>0.5$, PV $>80$ and dry gluten $>12 \%$. Under our conditions, alveograph $W$ and $P / L$ always exceeded the proposed limits, dry gluten was lower in all treatments and PV, which is an index including dry gluten and alveograph $W$ and $P / L$, was higher only with the higher $S$ rate. Therefore we cannot draw conclusive assessment about the quality of pasta that could be obtained from our experiment, although we found that it was effectively improved by $\mathrm{S}$ fertilisation.

In our research no significant interaction between $\mathrm{N}$ and $\mathrm{S}$ rates was observed. Indeed, both $\mathrm{N}$ and $\mathrm{S}$ application had a positive effect on grain yield, but the response to one fertiliser was independent from the level of the other. Thus, our results do not corroborate the hypothesis of Zhao et al. (1999a) and Flæte et al. (2005), asserting that crop response to $\mathrm{S}$ fertilisation depends on the amount of $\mathrm{N}$ fertiliser, and that $\mathrm{S}$ deficiency may be induced by a high amount of $\mathrm{N}$ supply. Our results also contrast with results obtained by GarridoLestache et al. (2005) under Mediterranean conditions, reporting grain yield responses to $\mathrm{N}$ but not to $\mathrm{S}$ fertilisation, in a combined $\mathrm{N}$ and $\mathrm{S}$ fertilisation experiment.

Quality characters were significantly correlated to both $\mathrm{N}$ and $\mathrm{S}$ concentration of grain, but for any given quality character the relationship was strongest with $\mathrm{S}$ concentration than with $\mathrm{N}$ concentration. SDS was the quality parameter that correlated most strongly with both $\mathrm{N}$ and $\mathrm{S}$ grain concentration. In addition, alveograph $W$ showed a high correlation with $\mathrm{S}$ concentration. Our results indicate that the achievement of a high $S$ concentration in grain is crucial to obtain high quality pasta product.

Correlation between grain $\mathrm{N}$ and $\mathrm{S}$ concentration, on the contrary, was low, and this is confirmed by the wide variation of the $\mathrm{N}: \mathrm{S}$ ratio in grain, ranging from 10.8 to 18.5 . An independent accumulation of $\mathrm{N}$ and $\mathrm{S}$ in grain was also reported by Lerner et al. (2006). These authors suggested that the amino acid composition of storage proteins changes with grain S concentration, so under high $S$ availability the synthesis and accumulation of $S$ rich storage proteins is favoured at the expense of S-poor proteins. It is reasonable to suggest that these changes in protein composition may be at least in part responsible for the relatively major alterations in quality characters in response to $S$ availability. These results are consistent with those from studies on bread wheat (Moss et al., 1981; Zhao et al., 1999b; Dupont et al., 2006).

\section{Conclusions}

Our results showed that $\mathrm{N}$ and application affected durum wheat grain yield and quality parameters of grain. Fertiliser $\mathrm{S}$ had a more consistent effect on grain quality than on grain yield. The increase of grain yield due to $S$ fertiliser was recorded only in one out of two years and is likely to depend to the leaching losses of S owing to high winter rainfall, while all grain quality parameters were improved by $\mathrm{S}$ application. No interactive effect between the two fertilisers was observed, indicating that both $\mathrm{N}$ and $\mathrm{S}$ contribute effectively in improving grain yield and quality, irrespective of the reciprocal level of application. Under our conditions, no proof of S deficiency in plants was found, but the positive effect of $S$ fertiliser on grain 
quality may suggest the application of S fertiliser even in regions not deficient of soil S. Genotypes differed for yield stability between years, in that grain production was decreased in the driest year only in the varieties Claudio and Creso, but they responded similarly to $\mathrm{N}$ and $\mathrm{S}$ fertilisation. Genotypes differed also for protein concentration and quality parameters, and, on average, the varieties Duilio, Simeto and Svevo gave better performances. Differences in grain quality parameters were maintained through years, indicating that that these traits are under strong genetic control.

\section{References}

Alary, R., Kobrehel, K., 1987. The sulfhydryl plus disulfide content in the proteins of durum wheat and its relationship with the cooking quality of pasta. J. Sci. Food Agric. 39, 13-136.

Archer, M.J., 1974. A sand culture experiment to compare the effects of sulphur on five wheat cultivars (T. aestivum L.). Aust. J. Agric. Res. 25, 369-380.

D’Egidio, M.G., Mariani, B.M., Nardi, S., Novaro, P., Cubadda, R., 1990. Chemical and technological variables and their relationships: a predictive equation for pasta cooking quality. Cereal Chem. 67, 275-281.

de Ruiter, J.M., Martin, R.J., 2001. Management of nitrogen and sulphur fertiliser for improved bread wheat (Triticum aestivum) quality. N Z J. Crop Hortic. Sci. 29, 287-299.

Dick, J.W., Quick, J.S., 1983. A modified screening test for rapid estimation of a gluten strength in early generation durum wheat breeding lines. Cereal Chem. 60, 315-318.

Dupont, F.M., Hurkman, W.J., Vensel, W.H. Chan, R., Lopez, R., Tanaka, C.K. Altenbach, S.B., 2006. Differential accumulation of sulfur-rich and sulfur-poor wheat proteins is affected by temperature and mineral nutrition during grain development. J. Cereal Sci. 44, 101-112.

Ercoli, L., Lulli, L., Mariotti, M., Masoni, A., Arduini, I., 2008. Post-anthesis dry matter and nitrogen dynamics in durum wheat as affected by nitrogen supply and soil water availability. Eur. J. Agron. 28, 138-147.

Eriksen, J., Olesen, J.E., Askegaard, M., 2002. Sulphate leaching and sulphur balances of an organic cereal crop rotation on three Danish soils. Eur. J. Agron. 17, 1-9.

Eriksen, J., 2009. Sulfur cycling in temperate agricultural systems. Adv. Agron. 102, 55-89.

Flæte, N.E.S., Hollung, K., Ruud, L., Sogn, T., Faergestad, E.M., Skarpeid, H.J., Magnus, E.M., Uhlen, A.K., 2005. Combined nitrogen and sulphur fertilisation and its effect on wheat quality and protein composition measured by SE-FPLC and proteomics. J. Cereal Sci. 41, 357-369.

Garrido-Lestache, E., Lopez-Bellido, R.J., Lopez-Bellido, L., 2005. Durum wheat quality under Mediterranean conditions as affected by $\mathrm{N}$ rate, timing and splitting, $\mathrm{N}$ form and S fertilization. Eur. J. Agron. 23, 265-278.

International Association of Cereal Chemistry (ICC), 1986. Standard Methods of the ICC. ICC, Vienna, Austria.

Kovacs, M.I.P., Poste, L.M., Butler, G., Woods, S.M., Leisle, D., Noll, J.S., Dahlke, G., 1997. Durum wheat quality: comparison of chemical and rheological screening tests with sensory analysis. J. Cereal Sci. 25, 65-75.

Landi, A., 1995. Durum wheat, semolina and pasta quality characteristics for an Italian food company. In: Di Fonzo, N., Kaan, F., Nachit, M. (Eds.), Durum Wheat Quality in the Mediterranean Region. ICARDA/CIHEAM/CIMMYT Zaragoza (Spain), 17-19 November 1993. Options Méditerranéennes Ser. A 22 33-42.
Lerner, S.E., Seghezzo, M.L., Molfese, E.R., Ponzio, N.R., Cogliatti, M., Rogers, W.J. 2006. N- and S-fertiliser effects on grain composition, industrial quality and end-use in durum wheat. J. Cereal Sci. 44, 2-11.

MacRitchie, F., Gupta, R.B., 1993. Functionality-composition relationships of wheat flour as a result of variation in sulfur availability. Aust. J. Agric. Res. 44 1767-1774.

McGrath, S.P., Zhao, F.J., Withers, P.J.A., 1996. Development of sulphur deficiency in crops and its treatments. In: Proc. of the Fertiliser Soc., No. 379 ,. The Fertilise Society, Peterborough.

Monaghan, J.M., Evans, E.J., Shewry, P.R., 1997. The effect of amount and timing of S on grain yield and quality of winter wheat. In: Gooding, M.J., Shewry, P.R. (Eds.), Aspects of Applied Biology 50, Optimising Cereal Inputs: Its Scientific Basis. The Association of Applied Biologists, Wellesbourne, UK, pp. 231-236.

Moonen, C., Masoni, A., Ercoli, L., Mariotti, M., Bonari, E., 2001. Long term changes in rainfall and temperature in Pisa, Italy. Agric. Med. 130, 11-22.

Mortensen, J., Eriksen, J., 1994. Effect of sulphur deficiency on amino acid composition. Norw. J. Agric. Sci. (Suppl. 15), 135-142.

Moss, H.J., Randall, P.J., Wrigley, C.W., 1983. Alteration to grain, flour and dough quality in three wheat types with variation in soil sulfur supply. J. Cereal Sci. 1, 255-264.

Moss, H.J., Wrigley, C.W., MacRichie, R., Randall, P.J., 1981. Sulfur and nitrogen fertilizer effects on wheat. II. Influence on grain quality. Aust. J. Agric. Res. 32 , 213-226.

Randall, P.J., Spencer, K., Freney, J.R., 1981. Sulfur and nitrogen fertiliser effects on wheat. I. Concentrations of sulfur and nitrogen and the nitrogen to sulfur ratio in grain, in relation to the yield response. Aust. J. Agric. Res. 32, 203-212.

Randall, P.J., Wrigley, C.W., 1986. Effects of sulfur supply on the yield, composition, and quality of grain from cereals, oilseeds, and legumes. Adv. Cereal Sci. Technol. 8, 171-206.

Salvagiotti, F., Castellarin, J.M., Miralles, D.J., Pedrol, H.M., 2009. Sulfur fertilization improves nitrogen use efficiency in wheat by increasing nitrogen uptake. Field Crops Res. 113, 170-177.

Scherer, H.W., 2001. Sulphur in crop production-invited paper. Eur. J. Agron. 14, 81-111.

Schnug, E., 1991. Sulphur nutritional status of European crops and consequences for agriculture. Sulphur Agric. 15, 7-12.

Schumacher, B.A., Neary, A.J., Palmer, C.J., Maynard, D.G., Pastorek, L., Morrison, I.K. Marsh, M., 1995. Laboratory methods for soil and foliar analysis in long-tem environmental monitoring programs. EPA/600/R-95/077, $178 \mathrm{pp}$.

Steel, R.G.D., Torrie, J.H., Dickey, D.A., 1997. Principles and Procedures of Statistics: A Biometrical Approach. McGraw-Hill, New York.

Stewart, B.A., Porter, L.K., 1969. Nitrogen-S relationship in wheat (Triticum aestivum L.), corn (Zea mays), and beans (Phaseolus vulgaris). Agron. J. 61, 267-271.

Timms, M.F., Bottomley, R.C., Ellis, J.R.S., Schofield, J.D., 1981. The baking quality and protein characteristics of a winter wheat grown at different levels of nitrogen fertilisation. J. Sci. Food Agric. 32, 648-698.

Wieser, H., Gutser, R., von Tucher, S., 2004. Influence of sulphur fertilisation on quantities and proportions of gluten protein types in wheat flour. J. Cereal Sci. 40, 239-244.

Zadoks, J.C., Chang, T.T., Konzak, C.F., 1974. A decimal code for the growth stages of cereals. Weed Res. 14, 415-421.

Zhao, F.J., Hawkesford, M.J., McGrath, S.P., 1999a. Sulphur assimilation and effects on yield and quality of wheat. J. Cereal Sci. 30, 1-17.

Zhao, F.J., Salmon, S.E., Withers, P.T.A., Monaghan, J.M., Evans, E.J., Shewry, P.R., McGrath, S.P., 1999b. Variation in the breadmaking quality and rheological properties of wheat in relation to sulphur nutrition under field conditions. J. Cereal Sci. 30, 19-31. 